\title{
Interactions between breeding group, sex and nutritional status in growing pigs
}

\author{
G. BOLET (1), B. DESMOULIN (2), P. SELLIER (1) et Y. HENRY ( $\left.{ }^{2}\right)$
}

(1) Station de Génétique quantitative et appliquée,

(2) Station de Recherches sur l'Elevage des Porcs,

I.N.R.A.-C.N.R.Z., 78350 Jouy-en-Josas (I. ance)

\begin{abstract}
Fattening and carcass traits of II 5 pigs sired by boars from two different breeds were recorded, in relation to nutritional variations, according to a factorial design $2^{4}$ : two breeding groups (French Landrace or Pietrain boars mated to French Landrace or Lavge White dams), two sexes (females and castrates), two levels or dietary digestible energy (3,0 and 3.3 Mcal respectively of $\mathrm{DE} / \mathrm{kg}$ ), two crude protein to digestible energy ratios in the finishing period $(47$ and $55 \mathrm{~g}$ crude protein respectively per Mcal DE), the latter level being applied to all pigs between 30 and $60 \mathrm{~kg}$ ). Diets were offered ad libitum and pigs were slaughtered at the mean live weight of $97.3 \mathrm{~kg}$. The nutritional variations generally gave similar responses in both breeding groups which did not differ to a significant extent in food efficiency as well as in body composition; nevertheless in Pietrain crosses, between 30 and $60 \mathrm{~kg}$, energy consumption and growth rate were lower with the diet containing $3.0 \mathrm{Mcal} \mathrm{DE} / \mathrm{kg}$. Some interactions between sex and diet were observed: the increase in the dietary cnergy content resulted in better results in females than in castrates; also maintaining the level of $5.5 \mathrm{~g}$ crude protein per Mcal DE during the finishing period was associated with a decreased energy consumption and consequently a reduced carcass fatness in castrates, but not in females.
\end{abstract}

\section{A comparison of the crossbred progeny of Large White and Pietrain boars : Influence of slaughter weight}

\author{
P. SELLIER \\ Station de Génétique quantitative et appliquéc, \\ I.N.R.A.-C.N.R.Z., 78350 Jouy-en-Josas (France)
}

Large White boars from two different populations were compared to Pietrain boars in terms of combining with French Landrace $\times$ Large White females. Pigs (females and castrated) were fed ad libitum (test starting at $30 \mathrm{~kg}$ ) and slaughtered half at 90 , half at $\mathrm{I}$ to $\mathrm{kg}$ live weight. Complete data were recorded on 288 pigs. Average daily gain and daily feed consumption were significantly lower in Pietrain crosses (XPP) than in Large White crosses (XLW). No significant difference between breeding groups was found in feed efficiency between 30 and $90 \mathrm{~kg}$ and between 30 and $110 \mathrm{~kg}$. With respect to body composition, XPP pigs presented a definite advantage which was somewhat higher when pigs were slaughtered at I I o kg. A superiority of XI,W pigs was evidenced for most of the criteria of meat quality, assessed 24 hours post mortem, the differences between breeding groups being generally smaller at IIo $\mathrm{kg}$. In overall economic merit taken as the benefit per pig, XPP pigs were better than both types of XLW pigs. When the criterion of overall merit is the benefit per pen and per year, the advantage of XPP still exists, except on pigs sired by boars from one of the Large White populations at the slaughter weight of 1 ro $\mathrm{kg}$ 